\title{
Development of routine RT-PCR tests for certification of fruit tree multiplication material*
}

\author{
J. Kummert ${ }^{1}$, M. Vendrame ${ }^{1}$, S. Steyer ${ }^{2}$ and P. Lepoivre ${ }^{1}$ \\ ${ }^{1}$ Faculté Universitaire des Sciences agronomiques, Unité de Phytopathologie, 2 Passage des Déportés, B-5030 Gembloux (Belgium), e-mail: \\ phytopat@fsagx.ac.be \\ ${ }^{2}$ Centre de Recherches agronomiques, Département de lutte biologique et ressources phytogénétiques, chemin de Liroux, B-5030 Gembloux \\ (Belgium)
}

\begin{abstract}
Current developments in certification procedures for propagating material require the availability of rapid, sensitive, reliable and user-friendly detection protocols applicable for routine testing. Our research concerns the possible use of reverse transcriptase-polymerase chain reaction (RT-PCR) for the detection of the pathogens listed for virus-tested pome and stonefruit propagating material in Belgium. Although RT-PCR satisfies the need for rapidity and sensitivity, the usual protocols relying on the use of purified nucleic acid preparations as template and ethidium bromide-stained agarose gels for detection are not appropriate for routine use. We therefore first optimized the parameters and cycling conditions of the RT-PCR reactions to allow direct use of crude extracts of either leaf or bark material as a template. Sandwich hybridization between a covalently linked capture probe and a biotinylated detection probe was then used for the detection of the specific amplicons (Lambdatech S.A. kits in development). These assays have the sensitivity and specificity of the RT-PCR, enhanced by sandwich hybridization with specific probes, and ease of sample preparation and detection of the amplicons. They make it possible to analyse a great number of samples and are thus well adapted for routine qualitycontrol testing of propagating material.
\end{abstract}

\section{Introduction}

Phytosanitary certification of planting material is becoming compulsory for an increasing number of crops. In the context of a European (or global) open market, becoming more competitive and rapid in the exchange of material, producers and laboratories in charge of the control of the certified propagating material are asking for sensitive and reliable tests adapted to the characteristics of the plant material, the pathogen (variability, threshold of inoculum, risk classification, etc.) and the market concerned. Such tests must give a guarantee of adequate sensitivity and specificity (in order to limit the probability of both false positive and false negative results to a small and prescribed range). They also need to be robust and reliable, and practicable for routine applications to large number of samples.

Although PCR (and RT-PCR) has reached wide acceptance in research laboratories for the diagnosis of plant pathogens (and particularly viruses) (Henson \& French, 1993), difficulties essentially linked to the steps before and after amplification pose major problems in its application in routine tests. Thus, sample preparation usually requires cumbersome and or expensive protocols. Moreover, although it is easy to

*Paper presented at the EPPO Conference on diagnostic techniques for plant pests, Wageningen (NL), 2000-02-01/04. detect amplified products by electrophoresis in ethidium bromide-stained agarose gels, the technique suffers from relative lack of both sensitivity and specificity, and cannot be automated. Accordingly, new and more reliable and convenient methods have to be developed before they can be accepted as reference protocols.

The present study focuses on the different steps which have to be taken into account for the development of rapid, costeffective and efficient detection kits based on RT-PCR, with respect to detection of viruses in certified 'virus-tested' fruittree propagating material. The different steps to be considered are: (1) the sample processing protocol, (2) optimization of the PCR assay (mainly selection of primers) and (3) detection of amplification products. The concept of the (RT)-PCR assay should integrate these three steps into the overall procedure: for example, correct design of primers will allow efficient amplification and thus simplification of sample processing (removing, for example, the need for a nucleic acid extraction/purification step). Product length, or presence of specific internal conserved sequences which can be of significance for the detection system used, also depend on choice of primers. Our research programme has concentrated on direct use of crude extracts submitted to efficient PCR or RT-PCR amplification, and detection of specific amplification products by a convenient microplate colorimetric assay. The procedures are illustrated by RT-PCR protocols developed for detection of 
Apple chlorotic leafspot closterovirus (ACLSV), Apple stem grooving capillovirus (ASGV) and Apple stem-pitting foreavirus (ASPV) in apple.

\section{Materials and methods}

\section{Plant material}

The plant material used for the development of the RT-PCR protocols for the detection of ACLSV, ASGV and ASPV consisted of herbaceous indicators inoculated with characterized isolates of ACLSV (Chenopodium quinoa), ASGV (C. quinoa and Nicotiana glutinosa) and ASPV (N. occidentalis 37B), and apple plants infected with one or several of these viruses. Validation of optimized RT-PCR protocols was conducted on samples taken on trees in the fields, or budwood from collections, orchards and nurseries.

\section{Sample processing}

Total RNA was extracted from $0.5 \mathrm{~g}$ of leaf or bark tissue, and ground in liquid nitrogen with a pestle and mortar according to the technique of Bugos et al. (1995). This technique uses Tris, $\mathrm{NaCl}$, EDTA extraction buffer, phenol-chloroform-isoamyl alcohol extraction and successive isopropanol and $\mathrm{LiCl}$ precipitations. The RNA concentration was calculated after determining the absorbance value at $260 \mathrm{~nm}$.

Crude extracts were obtained by homogenization of 50 $100 \mathrm{mg}$ of ground tissues in SCPAP buffer (Minsavage et al., 1994). Bark tissue was ground in liquid nitrogen, while fresh leaf tissue, or tissue from in vitro plantlets, was ground directly in the microtubes, in both cases in the presence of $5 \%$ polyvinylpyrrolidone.

\section{Design of specific primers and probes}

The specific primers and probes for ACLSV, ASGV and ASPV were selected by computer analysis with PLEUP, FASTA and PRIME programs (Wisconsin Package Version 10.0, Genetic Computer Group). These programs were applied to sequence data available in EMBL and Genbank databases as well as partial sequences obtained in the laboratory, in order to meet the technical requirements of both the RT-PCR reaction and the colorimetric detection of specific amplification products by sandwich hybridization with capture and detection probes.

\section{RT-PCR amplification}

RT-PCR amplifications were performed by the Titan one-tube RT-PCR system of Roche, with the specific primers presented in Fig. 1. A $25-\mu \mathrm{L}$ RT-PCR reaction mixture containing $0.2 \mathrm{mM}$ of each dNTPs, $0.4 \mu \mathrm{M}$ of both primers, 10 units of RNase inhibitor and the reagents from the Titan one-tube RTPCR system was submitted to cDNA synthesis (30 min at $55^{\circ} \mathrm{C}$ ) and PCR amplification with a denaturation of $2 \mathrm{~min}$ at $94{ }^{\circ} \mathrm{C}, 35$ cycles at $94^{\circ} \mathrm{C}, 30 \mathrm{~s} ; 55^{\circ} \mathrm{C}, 45 \mathrm{~s} ; 72^{\circ} \mathrm{C}, 1 \mathrm{~min}$; and a final extension of $10 \mathrm{~min}$ at $72^{\circ} \mathrm{C}$.

\section{Detection of amplification products}

\section{Gel electrophoresis}

Amplification products were analysed by electrophoresis of $10 \mu \mathrm{L}$ of the reaction mixture in $1 \%$ agarose gel in
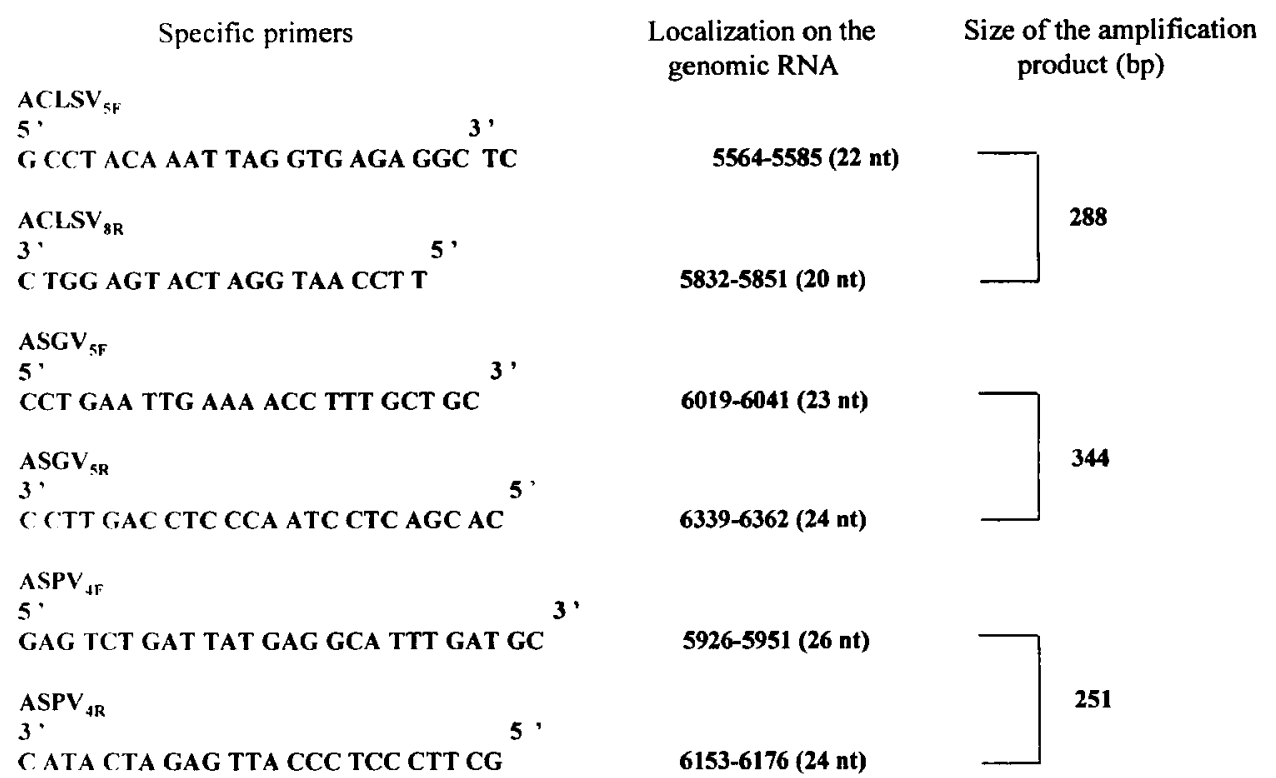

Fig. 1 Specific primers selected for the RT-PCR detection of ACLSV, ASGV or ASPV. 


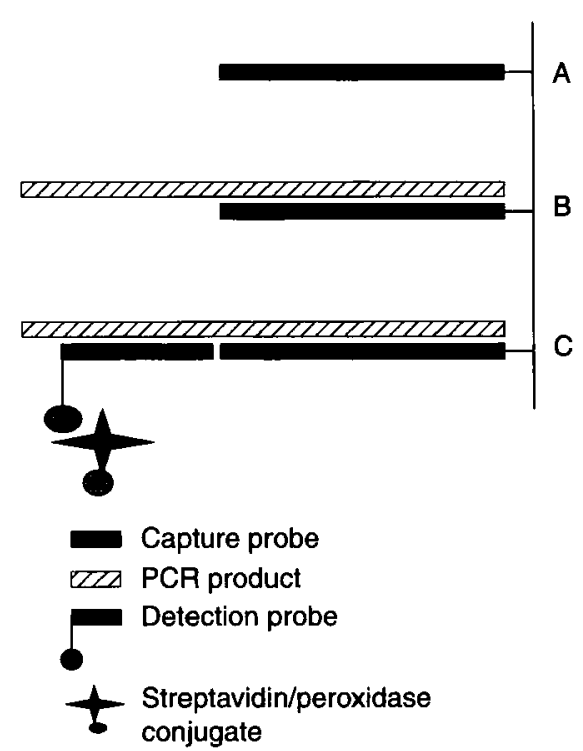

Fig. 2 Design of ELOSA system (Lambdatech S.A.) for detection of specific RT-PCR amplification products.

Tris-acetate-EDTA buffer and bands visualized under UV by ethidium bromide staining (Sambrook et al., 1989).

\section{Colorimetric detection in microplates}

The specific amplification products were detected after sandwich hybridization in microtiter plates or strips between a covalently linked capture probe produced by PCR and a $5^{\prime}$ biotinylated detection probe (Fig. 2). Both capture and detection probes are part of detection kits in development (Lambdatech S.A.; patent WO 98/11253). The capture probes are produced by PCR using specific RT-PCR amplification products cloned in plasmid vector PCR 2.1 (TA cloning kit, Invitrogen). The forward primer used for synthesis of a capture probe corresponds to the forward primer used in the RT-PCR reaction, shortened at its $3^{\prime}$ end and modified at its $5^{\prime}$ end by a phosphate group. The reverse primer corresponds to an internal sequence of the targeted RT-PCR product. The capture probe produced by PCR is denatured and immobilized on the plastic of the plate (Covalink, Nunc) by the protocol described by Rasmussen et al. (1991). The single-stranded detection probe, biotinylated at its $5^{\prime}$ end, is selected in a conserved region of the RT-PCR amplicon, and non-complementary to the capture probe. Prior to the hybridization, the amplicons were denatured $10 \mathrm{~min}$ at $100^{\circ} \mathrm{C}$. A hybridization at $55^{\circ} \mathrm{C}$ for $2 \mathrm{~h}$ was then performed between the capture probe, the denatured amplification product and the detection probe. A streptavidin-peroxidase conjugate was used for detecting the nucleic acid hybrids, by adding the substrate solution (3,3'-tetramethylbenzidine) and incubating the plate in the dark for $10 \mathrm{~min}$ at room temperature. The enzyme reaction was stopped by adding sulphuric acid. The hybridization buffer and washing buffer were those recommended by the manufacturer (Lambdatech). The optical density values were measured at $450 \mathrm{~nm}$ in a spectrometer Titertek Multiscan Plus.

\section{Results and discussion}

\section{Optimization of RT-PCR}

Amongst the first parameters which have to be optimized in PCR assays [reaction media, temperature, cycling scheme, enzyme(s) used], the primers are most important for successful amplification of specific sequences of plant pathogens. They have to meet different requirements in order to avoid false positive or false negative results. For example, the primers' Tm will impose the annealing temperature to be used during thermal cycling and thus the specificity (homology) of the target sequence fixed and processed. They will thus greatly determine the reliability and robustness of detection tests based on this technique, and govern their specificity.

For plant viruses concerned in the study, amplification has to be preceded by a reverse-transcription step. Previous work on RT-PCR detection of different RNA viruses had shown that the Titan one-tube RT-PCR system of Roche gave the best results in terms of reproducibility and sensitivity (Chandelier et al., 1998; Kummert et al., 1998; Marinho et al., 1998). This onetube system, designed for rapid and reproducible amplification of RNA sequences in a single optimized buffer, reduces the risks of contamination from tube to tube (sample to sample). The AMV reverse transcriptase used for cDNA synthesis allows the reaction to be performed at high temperature $\left(50-55^{\circ} \mathrm{C}\right.$ ), and the PWO polymerase mixed with Taq DNA polymerase ensures the accuracy of the DNA polymerization.

\section{Selection of specific primers}

Design of the primers was based on the study and comparison of available sequence data. The first step was to carefully select adequate target sequences, according to the desired specificity of the test (strains, species, genus). False negative results will be observed if the primers are selected without paying attention to the variability of different isolates of the same virus. On the other hand, artifactual products can be generated at low-annealing temperatures by use of primers which are too short, or show degeneracy or mismatching. Test efficiency will also be influenced by technical constraints linked to the primer sequences, the sequences and structures of the amplification product and possibly the detection probes.

Computer programs are very helpful for designing primers and simulating the PCR reaction. They take into account constraints linked to the primers themselves (length, GC content, $3^{\prime}$ clamp, sequence ambiguity, self-annealing, difference in $\mathrm{Tm}$, unique hybridization site, etc.) and also to the amplification products (length, GC content, absence of internal hybridization sites for primers, etc.). For analysis and comparison of sequences, and in searching for potential primers, we used Wisconsin Package Version 10.0 of the Genetic Computer Group. 


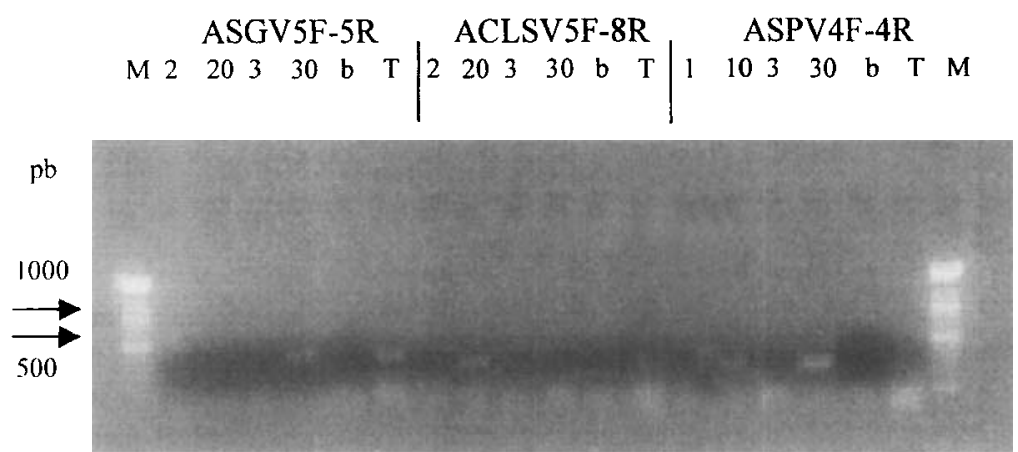

Fig. 3 Agarose gel electrophoresis of RT-PCR amplification products obtained from crude extracts of apple in the reference collection of Gembloux during winter with primer pairs ASGV5F-5R, ACLSV5F-8R and ASPV4F-4R. 1,10 , tree 91325 (final dilutions $20 \times, 200 \times$ in SCPAP buffer); 2,20 , tree 91328 (dilutions $20 \times$, $200 \times$ ); 3,30 , tree 10291 (dilutions $20 \times, 200 \times$ ); b, blank (negative control); $T$, positive control (Total RNA preparation from a plant infected by the homologous virus).
For certification purposes, detection tests have to recognize all the different isolates of a targeted pathogen and knowledge is needed of the (partial) sequences of several different isolates of the same agent (virus). For the different viruses concerned, we used sequences from EMBL and Genbank databases, as well as sequences kindly received from colleagues, collected from publications and also some partial sequences determined from local isolates.

For ACLSV, ASGV and ASPV, higher levels of homology were observed at the $3^{\prime}$ end of the genes coding for RNA polymerase and coat protein, and in the $3^{\prime}$ non-coding region. These regions were chosen for research of primers pairs (21-25 nt long, 45-55\% GC, content, $\mathrm{Tm} 55-65^{\circ} \mathrm{C}$ ) amplifying a product of $250-350 \mathrm{nt}$ length using the software PRIME. Amongst the several potential primers pairs thus obtained, very few could be retained after comparison with the alignment of the sequences of different isolates available for each virus. Some manual modifications or adjustments were often required (translation of a few nucleotides, combination of primers selected for two different pairs). In this case, the new primers had to be checked with the computer program. Finally, primer pairs ACLSV5F-8R, ASGV5F-5R and ASPV4F-4R, amplifying, respectively, the $3^{\prime}$ end of the RNA polymerase gene and the start of the coat protein genes of ACLSV, the $3^{\prime}$ end of the coat protein gene and beginning of the $3^{\prime}$ non-coding region of ASGV, and the $3^{\prime}$ end of the RNA polymerase gene of ASPV were selected. (Fig. 1). For all three viruses, optimized RT-PCR protocols were conducted with the Titan one tube RT-PCR system and the primer pairs selected, using the same thermal cycles with an annealing temperature of $55^{\circ} \mathrm{C}$.

\section{Sample processing}

The sample processing protocols should be adapted to the analysis of large numbers of samples and compatible with an efficient amplification reaction. As usual in research laboratories, the first development work was carried out with purified RNA preparations. For extracts from leaf and bark material from apple, best results were obtained with the techniques of Bugos et al. (1995), which includes phenol extraction and successive isopropanol and lithium chloride precipitations. Although very efficient (Kummert et al., 1998; Marinho et al., 1998), this technique is not well adapted for use in routine tests as needed for certification. For this purpose, the PCR assay has to be simplified and this means using crude plant extracts. As plant tissues often contain components interfering with the PCR reaction, the crude extracts have to be sufficiently diluted to allow a sufficient amplification (Rowhani et al., 1995).

For the RT-PCR tests developed with the new primer pairs, plant tissues (leaf and bark) were therefore ground in distilled water or with different buffers and additives. The extracts obtained were clarified by low-speed centrifugation submitted or not to heating, and $1 \mu \mathrm{L}$ of appropriate dilutions of these preparations was added to the RT-PCR mix (total volume $25 \mu \mathrm{L}$ ). Final dilutions of $10-20,100-200$ and $1000-2000$ were used. Best results were obtained when $50-100 \mathrm{mg}$ of

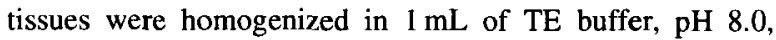
containing $0.02 \mathrm{M}$ ascorbic acid or sodium ascorbate, or SCPAP buffer (Minsavage et al., 1994).

Figure 3 shows an example of the RT-PCR test with direct use of crude extracts of bark tissue, diluted in SCPAP buffer,

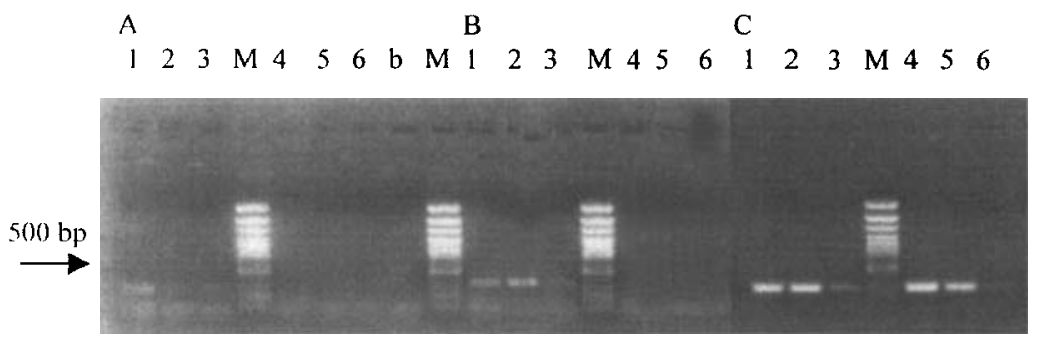

Fig. 4 Agarose gel electrophoretic analysis of RT-PCR amplification products obtained from crude extracts of bark tissue from 2 references apple trees with primer pairs ACLSV5F-8R (A), ASGV5F-5R (B) and ASPV4F-4R (C). 1,2,3, tree Al (extracts diluted $10 \times, 100 \times, 1000 \mathrm{x}$ ); 4,5,6, tree A4 (extracts diluted 10x,100x, 1000x); b, blank; M, marker (100 bp scale). 
Fig. 5 ELOSA detection of cloned target sequences by hybridization (at $50,55,60^{\circ} \mathrm{C}$ ) of capture ( $300 \mathrm{ng}$ per well) and detection (20 ng per well) probes defined for ACLSV and ASPV amplification products generated with primers ACLSV5F-ACLSV8R and ASPV4F-ASPV4R. A, ACLSV target sequences (product ACLSV5F-8R, clone C5); B, ASPV target sequences (product ASPV4F-4R, clone P5).
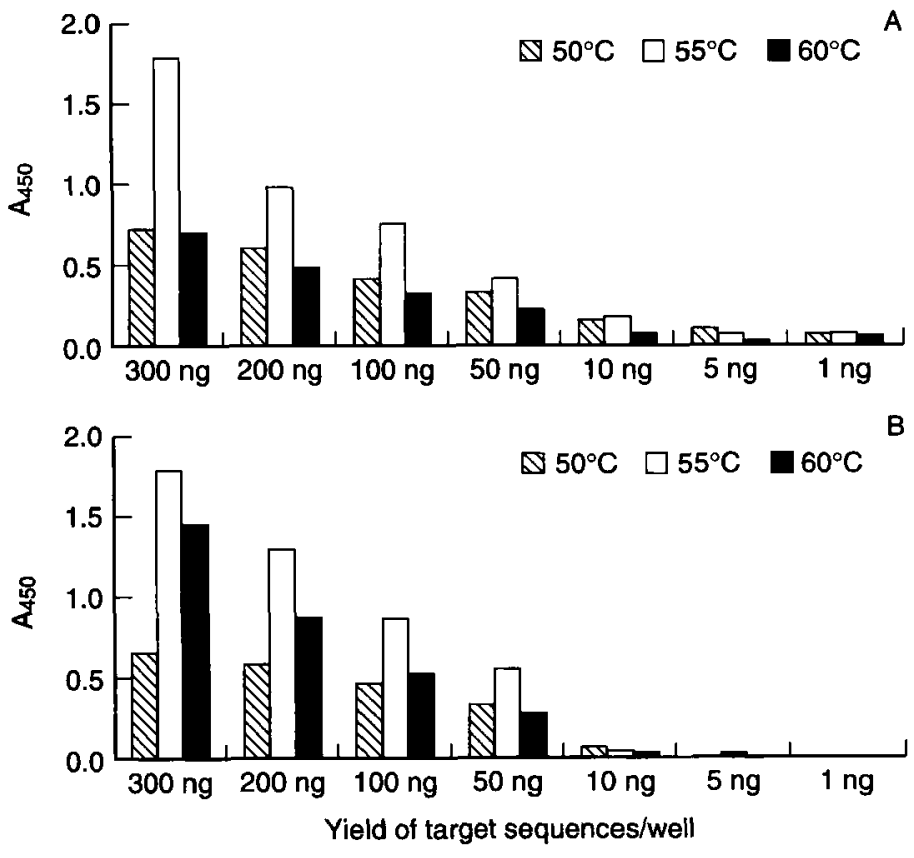

from three apple trees of our reference collection $\mathbf{( 9 1 3 2 5}$ positive for ASPV; 91328 positive for ACLSV and 10291 positive for ASGV and ASPV). A clear signal was seen in the gel when the crude extracts were diluted 200 times but not 20 times. This inhibition in less diluted extracts was not general, but depended on the tree, the virus, the type of tissue and the period of sampling. Figure 4 shows for two other trees (A4 positive for ASPV, and A1 positive for ACLSV, ASGV and ASPV) that the more intense signals in the gels are observed for the less diluted extracts. For this reason, we currently always use two dilutions $(10 \times, 100 \times)$ for RT-PCR reactions performed with crude extracts.

The optimized RT-PCR protocols developed for the detection of ACLSV, ASGV and ASPV from diluted crude extracts were shown to be efficient when applied to material from virus-infected material of different origins, reproducing the results previously observed for RT-PCR reactions using the same primer pairs and applied to total RNA preparations from samples taken on the same trees. They were particularly efficient for the specific detection of these three viruses in apple material grown in vitro.

\section{Detection of the amplification products}

We had previously developed colorimetric RT-PCR tests for diagnosis of ASGV in field-collected apple samples (Daniels
Fig. 6 Analysis of RT-PCR amplification products obtained with primers ASGV5FASGV5R from dilutions of crude sap of Nicotiana glutinosa inoculated with ASGV isolate 10311 . (A) electrophoretic analysis of amplification products [fluorescence band intense $(++)$, visible $(+)$ or absent $(-)$ on the gel]; (B) ELOSA detection.

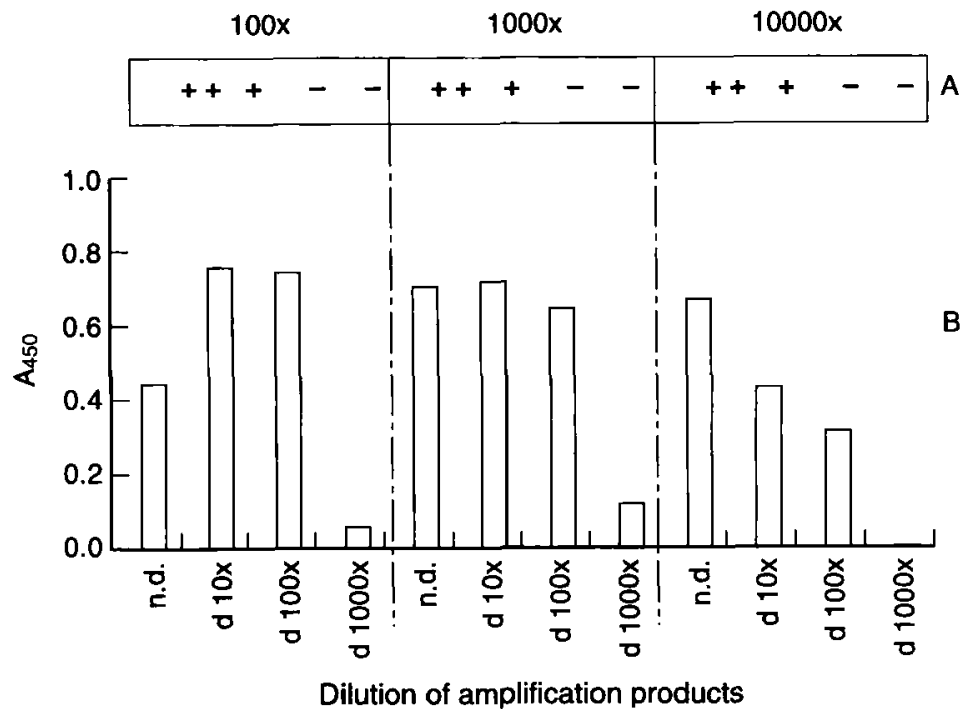


Dilution of crude extracts

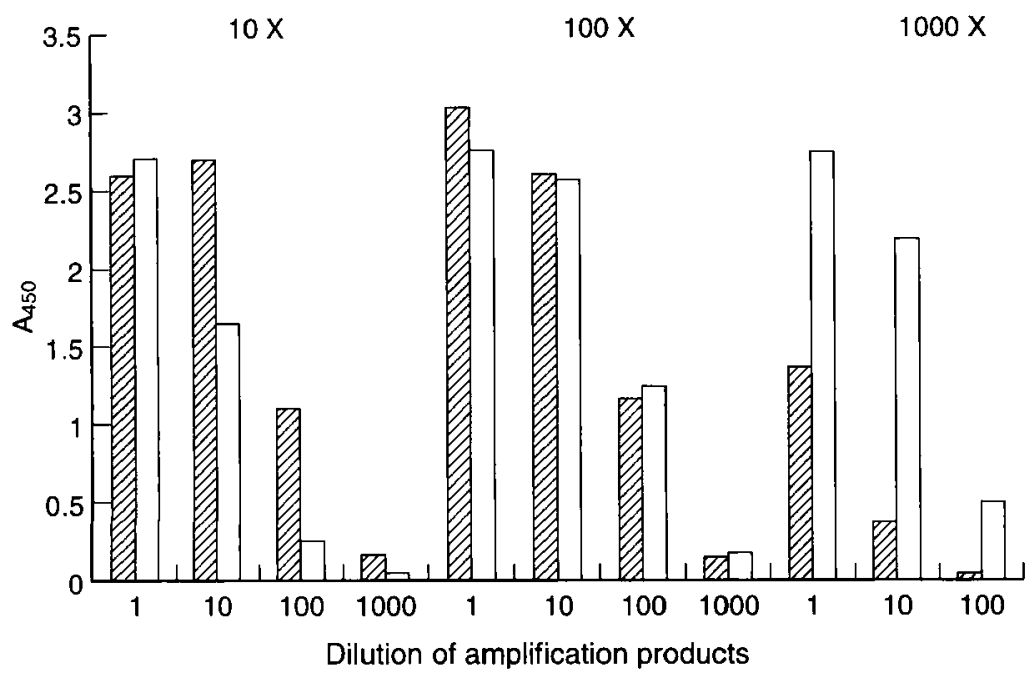

Fig. 7 Results of RT-PCR-ELOSA tests for the detection of ACLSV from crude extracts (dilution $10 \times, 100 \times$ or $1000 \times$ ) of bark tissues taken from apple twigs 91328 and $10392 \square$ the during winter. et al., 1998) based on the use of the biotin-digoxigenin system from Boehringer. Use of a biotin-labelled primer and direct labelling of PCR amplification products with digoxigenin gives rise to unspecific colorimetric detection. Use of a biotin-labelled specific oligo-probe and both digoxigeninlabelled PCR products, or unlabelled PCR products hybridized to a specific digoxigenin-labelled oligo-probe of the same polarity, gave specific results from ASGV-infected purified RNA preparations.

Design of the ELOSA detection of amplification products In view of the high specificity needed for certification, only protocols using sandwich hybridization of the amplification products with a capture and a detection probe were retained for further study. For uniformity and comparability of the detection tools developed for different pathogens of different crops in our laboratory, we designed the (RT)-PCR ELOSA detection tests according to the method of Lambdatech S.A. (Fig. 2).

Comparison of the sequences of different isolates of ACLSV, ASGV and ASPV available for the genome fragment amplified by the primer pairs selected for the RT-PCR amplification allowed us to define oligonucleotide detection probes and primers for the synthesis of capture probes. Detection probes (33-35 nt) corresponding to conserved sequences located near to the $3^{\prime}$ end of the amplification products were custom synthesized with biotin labelling at their $5^{\prime}$ end. Capture probes were synthesised by PCR from cloned characterized RT-PCR amplification products containing the fragment delimited by the primer pairs selected for the RT-PCR-ELOSA detection tests and obtained from total RNA preparations of plants infected by a single known virus isolate. The forward primers used for synthesis of capture probes corresponded to the forward primers of the RT-PCR, shortened and phosphorylated at their $5^{\prime}$ end, the reverse primers corresponded to an internal conserved region of the amplification product. The capture probes thus defined could be easily and reproducibly produced from homogeneous plasmid DNA. The capture probes defined for the three viruses corresponded, respectively, to $62 \%, 71 \%$ and $69 \%$ of the RT-PCR product obtained for ACLSV, ASGV and ASPV.

\section{Development and optimization of the ELOSA protocol}

ELOSA detection protocols were first developed by using cloned target DNA sequences corresponding to specific RTPCR amplification products from plants infected with a characterized ACLSV, ASGV or ASPV isolate. The different parameters to be considered for optimization of the ELOSA detection protocols were: concentration and temperature for fixation of the phosphorylated capture probes to the aminated plates or strips, concentration of detection probes and target sequences (or PCR products), temperature of hybridization of target sequences to capture and detection probes. For this optimization, all buffers and protocols used were those of Lambdatech S.A.

Figure 5 shows that for ACLSV and ASPV, the optimal temperature for hybridization with the capture and detection probes selected was $55^{\circ} \mathrm{C}$. The yield of target amplification products (here purified amplified cDNA fragments) used for ELOSA detection should be $300 \mathrm{ng}$ or more. This amount was readily obtained in diluted preparations from PCR amplification reactions from cloned target DNA, or RT-PCR amplification reactions from total RNA preparations, or even from crude extracts of virus-infected plant material (if the RT-PCR reaction has been carefully optimized).

For ACLSV and ASPV, the optimized protocols for ELOSA detection of amplification products ACLSV5F-8R and ASPV4F-4R with the selected probes used $20 \mathrm{ng}$ of detection probe per well, $300 \mathrm{ng}$ of capture probe per well, fixed at $50^{\circ} \mathrm{C}$ to aminated microplates, and hybridization of the two probes to specific amplification products at 
$55^{\circ} \mathrm{C}$ for $2 \mathrm{~h}$. The same conditions were also used for ASGV, but more optimization may be useful in this case, including perhaps the synthesis or definition of new probes.

Use of RT-PCR-ELOSA protocols for the detection of $A C L S V, A S G V$ and ASPV in samples of apple material

The ELOSA protocols defined and optimized by use of characterized, cloned and quantified target DNA were successfully used to detect specific RT-PCR amplification products obtained from crude extracts of herbaceous test plants, in vitro-grown virus-infected plantlets, or bark tissues of apple trees from the orchard (no leaf material was available at this time for experimentation). The experiments carried out with crude extracts of $N$. glutinosa infected by ASGV isolate 10311 (the same isolate as used to prepare the cloned amplification product used for the synthesis of the capture probe) showed the possibility of detecting RT-PCR amplification products obtained from crude extracts by ELOSA (Fig. 6). The detection of specific amplification products by ELOSA was more sensitive than electrophoresis in ethidium bromide-stained agarose gel. Because of competition between reannealing of the two strands of the amplicon and hybridization of complementary strands to capture and revelation probes, a higher ELOSA signal may be obtained from diluted amplification products. In some cases when high yields of amplification products are present (high fluorescence of amplification product visible in ethidium bromide-stained gel), as can readily be obtained with high amounts of purified RNA preparations from test plants, dilution of the RT-PCR reaction medium is needed to observe a colorimetric signal in ELOSA detection.

The experiments conducted with in vitro plantlets of apple showed that RT-PCR-ELOSA could be used and was reliable for detection of the 3 latent viruses in crude extracts diluted 10,100 or 1000 times.

First assays carried out in December on twigs of several trees from our reference collection in the orchard showed that RT-PCR-ELOSA tests can also be used for the detection of the three viruses in crude extracts obtained by grinding bark tissue in SCPAP buffer. Figure 7 illustrates the results obtained for bark tissue of two ACLSV-infected apple trees. The optimized RT-PCR-ELOSA protocol allowed specific detection of ACLSV in crude extracts from bark tissue (dormant wood during winter) diluted 1000 times; no significant inhibition of this RT-PCR-based detection was observed at a lesser dilution of the crude extracts $(100 \times)$. In these conditions (crude extracts), the amplification product did not have to be diluted before detection by ELOSA.

\section{Conclusions}

We have developed RT-PCR-ELOSA detection protocols using sandwich hybridization of specific PCR-amplified products to a phosphorylated capture probe and a biotinlabelled detection probe, followed by a colorimetric reaction on aminated microplates (streptavidin peroxidase conjugate using tetramethylbenzidine as template). These protocols have been optimized for ACLSV and ASPV, to allow detection of these viruses directly in leaf or bark tissue of apple. A similar protocol is in the process of optimization for the detection of ASGV and the same approach is being developed for prunus necrotic ringspot and prune dwarf ilarviruses.

\section{Acknowledgements}

This research was funded by the Belgian Ministry of Small Enterprises, Traders and Agriculture - DG6 (Research and Development) and DG4 (Quality of Plants and Plant Products), and by the European Commission - DGVI (Agriculture).

\section{Développement de tests RT-PCR de routine pour la certification du matériel de multiplication des arbres fruitiers}

Le développement des procédures de certification pour le matériel de multiplication suppose l'existence de protocoles de détection rapides, sensibles, fiables et faciles à mettre en oeuvre, applicables à des tests de routine. Nos recherches concernent la possibilité d'utiliser la RT-PCR pour la détection des agents pathogènes repris à la liste belge "virustested" pour le matériel de multiplication des arbres fruitiers à pépins et à noyau. Bien que la RT-PCR permette de satisfaire les exigences de rapidité et de sensibilité, les protocoles habituels, qui utilisent des préparations d'acides nucléiques purifiés comme modèle et l'électrophorèse en gels d'agarose colorés au bromure d'éthidium pour la détection, ne conviennent pas pour les tests de routine. Nous nous sommes donc d'abord attachés à optimiser les paramètres et les conditions de réalisation de la réaction RT-PCR, afin de permettre l'utilisation directe d'extraits bruts de feuilles ou d'écorces comme modèle. L'hybridation entre une sonde de capture fixée par des liaisons covalentes à une plaque de microtitration et une sonde de révélation biotinylée a ensuite été utilisée pour détecter les amplicons spécifiques (kits Lambdatech S.A. en cours de développement). Ces tests combinent la sensibilité et la spécificité de la RT-PCR, encore augmentées par l'hybridation sandwich à des sondes spécifiques, et la facilité de préparation des échantillons et de détection des amplicons. Ils rendent possible l'analyse d'un grand nombre d'échantillons et sont de ce fait bien adaptés aux tests de routine dans le cadre du contrôle de la qualité du matériel de multiplication.

\section{Разработка рутинного тестирования мето- дом RT-PCR для сертифицирования поса- дочного материала плодовых деревьев}

Последние достижения в процедурах сертифицирования посадочного материала требуют наличия оперативных, 
чувствительных, надежных и простых в применении протоколов выявления для рутинного тестирования. Исследование охватывает возможное использование RTPCR в целях выявления патогенов, внесенных в список проверенного на вирусы посадочного материала семечковых и косточковых в Бельгии. Хотя RT-PCR удовлетворяет требованиям по быстродействию и чувствительности, обычные протоколы, основанные на использовании очищенных нуклеиновых препаратов и электрофорезе в геле окрашенных бромистым этидием aгаро3, для рутинного выявления не подходят. Поэтому сперва оптимизировались параметры и условия протекания RT-PCR реакции, для того чтобы позволить прямое использование сырых экстрактов, либо листьев, либо коры в качестве матрицы. Сэндвичная гибридизация между ковалентно-связанным зондом захвата и биотинилированным зондом выявления использовалась для выявления специфических ампликонов (фирма Lambdatech S.A. разрабатывает наборы). Эти тесты сочетают в себе чувствительность и специфичность RTPCR, увеличенную за счет сэндвичной гибридизации с помощью специфичных зондов, с легкостью подготовки проб и выявления ампликонов. Они делают возможным анализировать большое число проб и таким образом хорошо приспособлены для рутинного тестирования качества посадочного материала.

\section{References}

Bugos RC, Chiang VL, Zhang XH, Campbell WH, Podila GK \&
Campbell WR (1995) RNA isolation from plant tissues recalcitrant to extraction in guanidine. Biotechniques 19, 734-737.

Chandelier A, Cognet S, Marinho VLA, Kummert J \& Lepoivre P (1998) Development of routine detection tests using PCR for certification. Mededelingen van het Faculteit van de Landbouwwetenschappen van het Universiteit te Gent 63/4b, 1473-1948.

Daniels J, Marinho VLA, Kummert J \& Lepoivre P (1998) Development of colorimetric RT-PCR tests for apple stem grooving virus detection in apple trees. Acta Horticulturae No. 472, 105-111.

Henson JM \& French R (1993) The polymerase chain reaction and plant diagnosis. Annual Review of Phytopathology 31, 81-109.

Kummert J, Marinho VLA, Rufflard G, Colinet D \& Lepoivre P (1998) Sensitive detection of apple stem grooving and apple stem pitting viruses from infected apple trees by RT-PCR. Acta Horticulturae No. 472, 97-104.

Marinho VLA, Kummert J, Rufflard G, Colinet D \& Lepoivre P (1998) Detection of apple stem grooving virus in dormant apple trees by using crude extracts as templates for one-step-RT-PCR. Plant Disease 82, 785-790.

Minsavage GV, Thompson CM, Hopkins DL, Leite RMVB \& Stall RE (1994) Development of a polymerase chain reaction protocol for detection of Xylella fastidiosa in plant tissue. Phytopathology 84, 456-461.

Rasmussen SR, Larsen MR \& Rasmussen SE (1991) Covalent immobilization of DNA onto polystyrene microwells: the molecules are only bound at the $5^{\prime}$ end. Analytical Biochemistry 198. $138-142$

Rowhani A, Maningas MA, Lile LS, Daubert SD \& Golino DA (1995) Development of a detection system for viruses of woody plants based on PCR analysis of immobilized virions. Phytopathology 85, 347-352.

Sambrook J, Fritsch E \& Maniatis T (1989) Molecular Cloning: a Laboratory Manual. Cold Spring Harbor Laboratory Press, New York (US). 